\title{
Article \\ Characterization of BoHV-1 gG-/tk-/gE- Mutant in Differential Protein Expression, Virulence, and Immunity
}

\author{
Marawan A. Marawan 1,2,3,*iD, Mingliang Deng ${ }^{1,2}$, Chen Wang ${ }^{1,2}$, Yingyu Chen 2,3,4,5, Changmin Hu ${ }^{2}$, \\ Jianguo Chen ${ }^{2}$, Xi Chen ${ }^{2}$, Huanchun Chen ${ }^{1,2,3,4}$ and Aizhen Guo 1,2,4,5,6,*
}

1 State Key Laboratory of Agricultural Microbiology, Huazhong Agricultural University, Wuhan 430070, China; dm1050806001@gmail.com (M.D.); wangchen2012@webmail.hzau.edu.cn (C.W.); chenhch@mail.hzau.edu.cn (H.C.)

2 College of Veterinary Medicine, Huazhong Agricultural University, Wuhan 430070, China; chenyingyu@mail.hzau.edu.cn (Y.C.); hcm@mail.hzau.edu.cn (C.H.); chenjg@mail.hzau.edu.cn (J.C.); chenxi@mail.hzau.edu.cn (X.C.)

3 Infectious Diseases, Animal Medicine Department, Faculty of Veterinary Medicine, Benha University, Toukh 13736, Egypt

4 Hubei International Scientific and Technological Cooperation Base of Veterinary Epidemiology, Key Laboratory of Preventive Veterinary Medicine in Hubei Province, Wuhan 430070, China

5 Key Laboratory of Development of Veterinary Diagnostic Products, Ministry of Agriculture, Huazhong Agricultural University, Wuhan 430070, China

6 Key Laboratory of Ruminant Bio-Products of Ministry of Agriculture and Rural Affairs, Huazhong Agriculture University, Wuhan 430070, China

* Correspondence: marawan.adel@fvtm.bu.edu.eg (M.A.M.); aizhen@mail.hzau.edu.cn (A.G.); Tel.: +20-122-687-2011 (M.A.M.); +86-278-728-6861 (A.G.); Fax: +20-013-246-3074 (M.A.M.); +86-278-728-6861 (A.G.)

Citation: Marawan, M.A.; Deng, M.; Wang, C.; Chen, Y.; Hu, C.; Chen, J.;

Chen, X.; Chen, H.; Guo, A.

Characterization of BoHV-1 gG-/tk-/ gE- Mutant in Differential Protein Expression, Virulence, and Immunity. Vet. Sci. 2021, 8, 253. https://doi.org/ $10.3390 /$ vetsci 8110253

Academic Editor: Atsushi Kato

Received: 27 August 2021

Accepted: 25 October 2021

Published: 27 October 2021

Publisher's Note: MDPI stays neutral with regard to jurisdictional claims in published maps and institutional affiliations.

Copyright: (c) 2021 by the authors. Licensee MDPI, Basel, Switzerland. This article is an open access article distributed under the terms and conditions of the Creative Commons Attribution (CC BY) license (https:// creativecommons.org/licenses/by/ $4.0 /)$.

\begin{abstract}
Infectious bovine rhinotracheitis (IBR), caused by bovine alphaherpesvirus 1 (BoHV-1), is an important disease affecting cattle worldwide resulting in great economic losses. Marker vaccines are effective in controlling infectious diseases including IBR, because they allow the discrimination between the natural infection and the vaccination. Therefore, a triple gene deleted strain BoHV-1 gG-/tk-/gE- was developed and evaluated in vivo and in vitro as a marker vaccine. In cell culture, this triple mutant virus showed significantly slower growth kinetics and smaller plaques when compared to wild-type (wt) BoHV-1 and double mutant BoHV-1 gG-/tk- $(p<0.01)$. On proteomic level, it revealed downregulation of some virulence related proteins including thymidine kinase, glycoproteins G, E, I, and $\mathrm{K}$ when compared to the wt. In vitro, the triple mutant virus showed a significantly lower and shorter viral shedding period $(p<0.001)$ in calves compared to double mutant. Moreover, the immunized calves with triple mutant virus showed protection rates of $64.2 \%$ and $68.6 \%$ against wt BoHV-1 and wt BoHV-5 challenge, respectively, without reactivation of latency after dexamethasone injection. In conclusion, BoHV-1 gG-/tk-/gE- is a safer marker vaccine against IBR although its immunogenicity in calves was decreased when compared to double mutant virus.
\end{abstract}

Keywords: bovine herpesvirus 1,5; proteomics; glycoprotein; marker vaccines; virulence; immunity

\section{Introduction}

Bovine alphaherpesvirus-1 (BoHV-1), the causative agent of infectious bovine rhinotracheitis disease (IBR) is a Varicellovirus genus member that belongs to subfamily Alphaherpesvirinae under the family Herpesvirida [1]. Alphaherpesviruses are double-stranded DNA viruses and their genome is at least $120 \mathrm{~kb}$ long, encoding for 70 or more genes [2].

Three antigenically similar subtypes of BoHV-1 have been revealed depending on the genomic analysis and viral peptide patterns namely, BoHV-1.1, BoHV-1.2a, and BoHV$1.2 \mathrm{~b}$ [3]. Furthermore, the disease outcome based on the BoHV-1 subtypes in which BoHV1.1 is the most predominant and mainly culminated in IBR with respiratory signs whilst 
BoHV-1.2 which can be divided into BoHV-1.2a and BoHV-1.2b has a broad range of clinical manifestations including IBR, infectious pustular vulvovaginitis, and balanoposthitis [4,5]. On the other hand, BoHV-5 is neuropathogenic and responsible for fatal meningoencephalitis [6]. The long-life latency development in the sensory ganglia and the existence of carrier animals are pivotal and serious features of BoHV-1 infections that render the control of the disease not feasible due to induction of reactivation from latency that was mimicked by various stressors particularly the synthetic corticosteroid dexamethasone [2,7].

Vaccination is the most successful way to control and eradicate IBR with some disadvantages related to the types of vaccines, either the inactivated and or attenuated IBR conventional vaccines. To overcome these disadvantages, genes that are virulence-related but non-essential for viral viability are the targets to be deleted for novel vaccine preparation $[8,9]$. Commonly used genes in development of gene-deleted vaccines to IBRV are from glycoprotein mutants such as Envelope glycoprotein E (gE), Envelope glycoprotein $\mathrm{G}(\mathrm{gG})$, and Envelope glycoprotein $\mathrm{N}(\mathrm{gN})$, and some genes coding for important enzymes such as Thymidine kinase (tk) $[10,11]$. Further, multiple deletion in one construct is considered to decrease the virulence and risk of the back-mutation such as gE-/tk- $[12,13]$, gE-/gG-/Tegument protein US2- [14], and gN-30-32CT-null/gE-CT-/Envelope protein US9- [15]. On the other hand, proteins are the core mediators of viral functions and any abnormal alteration on their abundance or expression levels may reflect the modification in viral pathological processes and immunity inside the hosts [16]. Usually attenuation of viral virulence is associated with decrease of viral immunogenicity.

Previously, our group has successfully constructed and characterized a double deleted strain BoHV-1 gG-/tk-, which was attenuated in calves and yet maintained the ability to stimulate a protective immune response [17]. Based on it, the construction and characterization of triple mutant BoHV-1 gG -/tk-/gE- was carried out and differential protein expression investigated by proteomic analysis using label-free quantitative proteomics (LFQP). Then, in vivo evaluation of the virulence and protective efficacy of this triple mutant strain against homologous BoHV-1 and heterologous BoHV-5 challenge in calves was performed to determine its potential application as a novel IBR marker vaccine.

\section{Materials and Methods}

\subsection{Ethics Statement}

The protocols regarding animal experiments were approved by the Committee on the Ethics of Animal Experiments at Huazhong Agricultural University and conducted in strict accordance with the Guide for the Care and Use of Laboratory Animals, Wuhan, Hubei, China.

\subsection{Cell Culture and Virus Strains}

Madin-Darby Bovine Kidney (MDBK) cell line was used for virus propagation. The cells were cultured with the complete medium Dulbecco's Modified Eagle's Medium (DMEM) containing 10\% fetal calf serum (FCS), $100 \mu \mathrm{g} / \mathrm{mL}$ streptomycin, and $100 \mathrm{IU} / \mathrm{mL}$ penicillin in a humidified incubator at $37{ }^{\circ} \mathrm{C}$ and $5 \% \mathrm{CO}_{2}$ as described previously [18].

Three BoHV-1 strains were used: (i) wt BoHV-1 of bovine origin isolated from a diseased calf with a respiratory sign by our laboratory. (ii) The wt BoHV-5 strain was kindly provided by Fabrício Campos at Federal University of Rio Grande doSul (UFRGS), Porto Alegre, Brazil. Finally, (iii) double mutant strain BoHV-1 gG-/tk-, a vaccine strain with deleted $\mathrm{gG}$ and $\mathrm{tk}$, was constructed and characterized by this lab as reported previously [19]. The three strains at a titer of $10^{7} \mathrm{PFU} / \mathrm{mL}$ (plaque forming unit/mL) were stored as viral stocks and used for MDBK cell infection with DMEM containing 2\% FCS.

\subsection{Construction of Triple Mutant Virus BoHV-1 Strain $g G-/ t k-/ g E-$}

2.3.1. Construction of Transfer Vector pBoHV-1 gE-

The primer pairs P1/P2 with Hind III/Kpn I sites and P3/P4 with BamH I/EcoR I sites were designed to amplify gE-upstream homologous arm and downstream homologous 
arm, respectively (Table S1). Similarly, the primer pair P5/P6 with KpnI/BamHI sites were used to amplify the enhanced green fluorescent protein (egfp) gene expression cassette. The resultant gE upper arm, egfp gene, and gE lower arm were cloned sequentially into pcDNA3.1 (+) myc-HisB to obtain recombinant plasmid pBoHV-1 gE- (Figure S1A).

\subsubsection{Generation and Characterization of the Triple Mutant Virus}

The linear plasmid pBoHV-1 gE- and full-length BoHV-1 gG-/tk- viral genomic DNA (the plasmid was cut firstly by restriction enzyme Hind III and BamH I) was purified and then co-transfected into MDBK cells for homologous recombination by using the calcium phosphate method as described previously [17]. The putative recombinant viral plaques were picked and subsequently purified for five rounds. The mutants were analyzed subsequently to determine the deletion of gE gene by various strategies of PCR using the primers (Table S1) specific to different fragments of the $\mathrm{gE}$ gene region and the PCR products were sequenced for confirmation (Sangon Biotech, Shanghai, China) (Figure S1B,C).

Four pairs of primers including P7/P8 (Lanes 1-4), P11/P12 (Lanes 5-8), P3/P14 (Lanes 9-12), and P7/P10 (Lanes 13-16) were used for identification of wt BoHV-1 and difference gene-deleted mutants (Figure 1A). Moreover, three pairs of primers including P7/P8 (Lanes 1-3), P9/P10 (Lanes 4-6), P7/P10 (Lanes 7-9) were used for further identification of BoHV-1 gG-/tk-/gE- mutant. Each pair of primers set has three repeats (Figure 1B).

$\mathbf{A}$

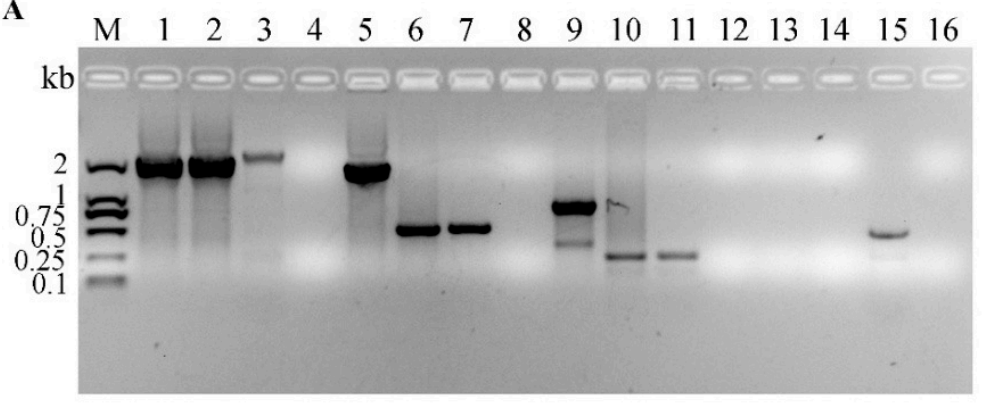

$\mathbf{B}$

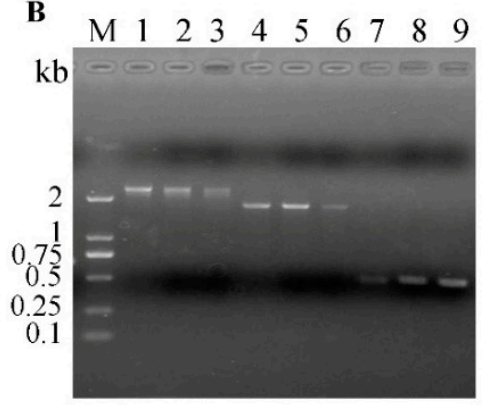

Figure 1. Identification of BoHV-1 gG-/tk-/gE- triple mutant by PCR. (A) A fragment of $2183 \mathrm{bp}$ of the intact gE gene fragment in wt BoHV-1 (Lane 1) and BoHV-1 gG-/tk- (Lane 2), and a fragment of 2395 bp including the whole egfp gene and parts of the flanking upstream and downstream sequences (Lane 3) are shown. In addition, the gG gene fragment in wt BoHV-1 (Lane 5), BoHV-1 gG-/tk- (Lane 6), and BoHV-1 gG-/tk-/gE- (Lane 7), and the tk gene fragment in wt BoHV-1 (Lane 9), BoHV-1 gG-/tk- (Lane 10), and BoHV-1 gG-/tk-/gE- (Lane 11) are shown. A fragment of 481 bp including parts of upstream homologous arm gene and egfp gene was detected in BoHV-1 gG-/tk-/gE- (Lane 15), but not in wt BoHV-1 (Lane 13), BoHV-1 gG-/tk- (Lane 14). Lanes 4, 8, 12, 16 represent negative control. (B) A fragment of 1685 bp including the whole upstream homologous arm gene, parts of the flanking upstream sequences of the upstream homologous arm gene, and egfp gene were amplified from BoHV-1 gG-/tk-/gE- mutant (Lane 4-6). M represents DNA ladder DL2000.

\subsection{Viral Growth Kinetics and Plaque Size Determination}

For growth characteristics comparison, the plaque morphologies and one-step growth curves of the three viruses were determined and compared as described elsewhere [19].

\subsection{Label Free Quantitative Proteomics (LFQP)}

\subsubsection{Virions Purification}

Viral purification was carried out using the sucrose density gradient ultracentrifugation method (Figure S2A). The resultant viral pellets were resuspended in $200 \mu \mathrm{L} 1 \times \mathrm{TE}$ buffer (10× TE buffer (1000 mL): 20 mL 500 mM/L EDTA (pH 8.0) and $100 \mathrm{~mL} 1 \mathrm{M} / \mathrm{L}$ Tris $\mathrm{HCl}$ buffer ( $\mathrm{pH} 8.0$ ) were added to water and final volume was $1000 \mathrm{~mL} .1 \times \mathrm{TE}$ buffer was prepared by diluting $10 \times$ TE buffer. Finally, $5 \mathrm{~mL}$ pure virus in TNE of each strain were obtained. Meanwhile the OD260/OD280 ratio was measured to be $0.5,0.4$, and 0.5 for wt, double mutant, and triple mutant, respectively, and the total protein concentration was 
calculated to be $3526.6,2728.0$, and $3370.8 \mu \mathrm{g} / \mathrm{mL}$. The viral products were divided into several aliquots and kept at $-80{ }^{\circ} \mathrm{C}$ for further use.

\subsubsection{LC-MS/MS Analysis}

LC-MS/MS analysis was performed on $500 \mu \mathrm{L}$ viral products (Project\# Z9358LQ, PTM-Biolabs Co., Ltd., Hangzhou, Zhejiang, China). Briefly, the viral samples experienced protein extraction and quantification, and trypsin digestion [20]. Then the resultant tryptic peptides were dissolved and fractionated using UPLC system and subjected to NSI source followed by tandem mass spectrometry (MS/MS) in Q Exactive TM Plus (Thermo Scientific ${ }^{\mathrm{TM}}$ Orbitrap Fusion Lumos ${ }^{\mathrm{TM}}$, Hangzhou, Zhejiang, China). The fixed first mass was set as $100 \mathrm{~m} / \mathrm{z}$ (Figure S2B). The MS data validation is shown in Figure S3 and was carried out using peptide mass tolerance distribution (Figure S3A), identified peptide length distribution (Figure S3B), and protein mass and coverage distribution (Figure S3C).

\subsubsection{Database Search and Bioinformatic Analysis}

The resulting MS/MS data were processed using the Maxquant search engine (v.1.5.2.8 http:/ / www.maxquant.org, access on 20 September 2020). The spectral data were searched against the target BoHV-1 Bos Taurus referenced protein database downloaded from UniProt (Universal Protein Resource) (www.uniprot.org, access 25 October 2021). Bioinformatic analysis was performed using Gene Ontology (GO) annotation proteome and was classified based on three categories: biological process, cellular component, and molecular function. In addition, a 1.5-fold-change was used as the threshold of differential expression change, and the statistical $t$-test with $p<0.05$ was used as the threshold of significance. Further, the quantitative ratio over 1.5 was considered upregulation while the quantitative ratio less than 1.5 as downregulation.

\subsection{Cattle Experiments}

Virulence and protective efficacy of the triple deletion mutant were evaluated in two-month-old weaned male Holstein calves that were seronegative for BoHV-1 $(n=24)$ (purchased from Hubei Center of Disease Control). The animal experimental design is summarized in Table 1. Each group of calves was housed in a separate room to prevent intergroup transmission. The animals were anesthetized by spray with $10 \%$ Lidocaine on the nasal cavity of the calves before the infection, vaccination, and challenge which was as used by Valera et al. [21]. Nasal swabs were collected daily in $2 \mathrm{~mL}$ of tissue culture medium supplemented with $2 \%$ penicillin and streptomycin for 14 days following virus exposure and dexamethasone injection. Blood was collected weekly up to the end of the experiments. The samples were processed and stored at $-80^{\circ} \mathrm{C}$. The animals were euthanized at the end of the experiments and the lung tissues were sampled for pathological examination.

Table 1. Experimental design.

\begin{tabular}{|c|c|c|c|c|c|c|c|}
\hline Animal & Virus & No & $\begin{array}{c}\text { Vaccinated } \\
\text { Route and Dose }\end{array}$ & Dex Injection ${ }^{a}$ & Challenge Virus & $\begin{array}{l}\text { Challenge Date } \\
\text { and Dose }\end{array}$ & $\begin{array}{l}\text { Euthanasia and } \\
\text { Necropsy }\end{array}$ \\
\hline \multirow{5}{*}{ Calf } & BoHV-1 gG-/tk-/gE- & 6 & $\mathrm{IN}, 4 \times 10^{7} \mathrm{PFU}$ & $21-25$ dpi & $\begin{array}{l}\text { wt BoHV-1 (3) }{ }^{b} \\
\text { wt BoHV-5 (3) }\end{array}$ & $35 \mathrm{dpi}, 4 \times 10^{7} \mathrm{PFU}$ & $28 \mathrm{dpc}$ \\
\hline & BoHV-1 gG-/tk- & 6 & $\mathrm{IN}, 4 \times 10^{7} \mathrm{PFU}$ & $21-25$ dpi & \multirow[t]{2}{*}{$\begin{array}{l}\text { wt BoHV-1 (3) } \\
\text { wt BoHV-5 (3) }\end{array}$} & $35 \mathrm{dpi}, 4 \times 10^{7} \mathrm{PFU}$ & $28 \mathrm{dpc}$ \\
\hline & wt BoHV-1 & 3 & $\mathrm{IN}, 4 \times 10^{7} \mathrm{PFU}$ & $21-25$ dpi & & $35 \mathrm{dpi}, 4 \times 10^{7} \mathrm{PFU}$ & $28 \mathrm{dpc}$ \\
\hline & Unvaccinated control & 6 & DMEM & $21-25 \mathrm{dpi}$ & \multirow[t]{2}{*}{$\begin{array}{l}\text { wt BoHV-1 (3) }{ }^{b} \\
\text { wt BoHV-5 (3) }\end{array}$} & $35 \mathrm{dpi}, 4 \times 10^{7} \mathrm{PFU}$ & $28 \mathrm{dpc}$ \\
\hline & Negative control & 3 & & & & & $28 \mathrm{dpc}$ \\
\hline
\end{tabular}

a: Dexamethasone (dex) at $0.1 \mathrm{mg} / \mathrm{kg}$ body weight (bwt) was injected intramuscularly into the calves for 5 consecutive days to reactivate the putatively latent virus. ${ }^{b}$ : Six vaccinated calves were allotted randomly to two sub-groups, and three calves in each sub-group were challenged with wt BoHV-1 and wt BoHV-5, respectively. The dpi refers to days post-infection while the dpc refers to days post-challenge. 


\subsubsection{Clinical Evaluation}

The animals' body temperature, behavior, presence of coughs, abnormal respiration, ocular and nasal discharges, hyperemia or lesions of the nasal mucosa, and conjunctivitis were monitored and recorded daily, and clinical scores were assigned for each parameter as described earlier [22]. Neurological signs were recorded in the wt BoHV-5 challenge experiment. The daily clinical score of each calf was the sum of the scores of all clinical parameters. The mean daily clinical score was calculated for each group and compared among groups.

\subsubsection{Virus Isolation and Titration}

Nasal swabs were used for virus isolation and titrations as described previously [23].

\subsubsection{Serological Investigation}

Serum samples were collected at different time points after vaccination or challenge and submitted to a standard virus-neutralizing (VN) assay as described earlier [23]. Sera were also submitted to BoHV-1 gB-specific antibody test (IDEXX Laboratories, Westbrook, ME, USA), BoHV-1 gE-specific antibody test (IDEXX Laboratories, Westbrook, ME, USA), sIgA (Bethyl Laboratories, Montgomery, TX, USA), and serum cytokine tests including IFN- $\gamma$ (Mabtech, Nacka Strand, Sweden), IL-2 (Ray Biotech, Norcross, GA, USA), and IL-4 (Mabtech, Nacka Strand, Sweden) detection by using commercial ELISA kits.

\subsubsection{Histo-Pathological Examination of Lungs}

The calves were euthanized $28 \mathrm{dpc}$ and a 35-point scoring system was used for the lesion evaluation in each lung lobe as described previously [24].

The lesion evaluation in each lung lobe was as follows: 0 , indicated no visible lesions; 1 , no gross lesions, but lesions were apparent upon dissection; $2,<5$ gross lesions with diameters of $<10 \mathrm{~mm} ; 3,>6$ gross lesions with diameters of $<10 \mathrm{~mm}$, or a single distinct gross lesion with a diameter of $>10 \mathrm{~mm} ; 4,2$ or more distinct gross lesions with diameters of $>10 \mathrm{~mm} ; 5$, gross coalescing lesions. The scores of the individual lobes were summed to generate the total lung score.

\subsection{Statistical Analysis}

The protection rate was calculated according to the formula described by Zhang et al. [25]. The data for the various groups were compared using $t$-tests and a one-way ANOVA. Results of comparisons with $p<0.05\left(^{*}\right)$ or $p<0.01\left(^{* *}\right)$ or $p<0.001\left(^{* * *}\right)$ were considered to indicate a significant or high significant statistical difference.

\section{Results}

3.1. Construction and Characterization of the Recombinant BoHV-1 gG-/tk-/gE- TripleDeleted Mutant

The BoHV-1 gG-/tk-/gE- virus was confirmed by PCR (Figure 1). A fragment of $2395 \mathrm{bp}$ (primers P7/8) including the whole egfp gene and parts of the flanking upstream and downstream sequences (Figure 1A, Lane 3), and a fragment of $481 \mathrm{bp}$ (primers P7/10) including parts of upstream homologous $\mathrm{gE}$ arm and egfp gene (Figure 1A, Lane 15) were amplified from the triple mutant, respectively. The deleted $\mathrm{gG}$ and tk gene fragments in BoHV-1 gG-/tk-/gE- were also detected (Figure 1A, Lanes 7 and 11, respectively). Additionally, a fragment of $1685 \mathrm{bp}$, including the whole upstream homologous gE arm gene, parts of the flanking upstream sequences of the upstream homologous $\mathrm{gE}$ arm, and egfp gene were amplified from the triple mutant (Figure 1B, Lanes 4-6). The PCR products of the mutant were custom-sequenced and the viral $\mathrm{gE}$ gene was found to be replaced with egfp gene. 


\subsection{Comparative Viral Growth Kinetics and Plaque Size Estimation}

Compared to wt BoHV-1 and BoHV-1 gG-/tk-, BoHV-1 gG-/tk-/gE- showed a weaker cell cytopathic effect (CPE) in MDBK cells shown by smaller plaques with uncleared edges within $48 \mathrm{~h}$ post-infection (hpi) (Figure 2A). The mean diameter of BoHV-1 gG-/tk-/gEplaques was $308 \pm 20 \mu \mathrm{m}, 48 \mathrm{hpi}$, which was significantly less than wt BoHV-1 and the BoHV-1 gG-/tk- mutant $(p<0.001)$ (Figure $2 \mathrm{~B}$ ). The growth curves of these three viruses were similar during the first $6 \mathrm{~h}$, however, the amount of BoHV-1 gG-/tk-/gE- virus produced was less than the wt BoHV-1 virus and BoHV-1 gG-/tk- mutant at the remaining time points $(p<0.001)$ until 48 hpi (Figure 2 C).

A

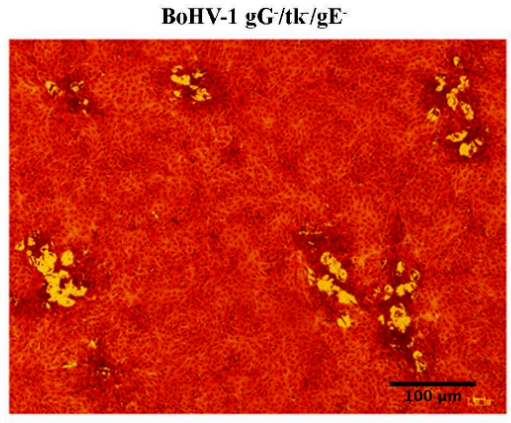

wt BoHV-1

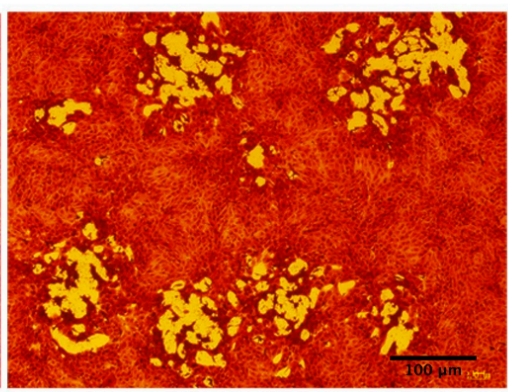

BoHV-1 gG-/tk-

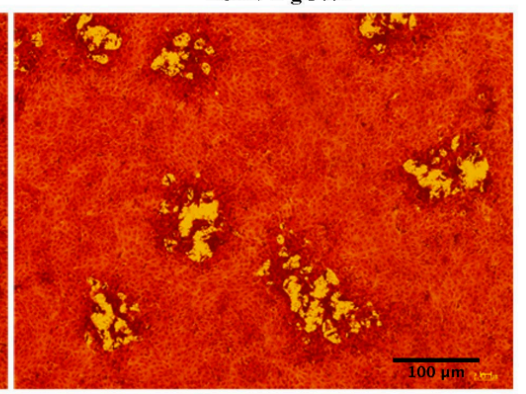

B

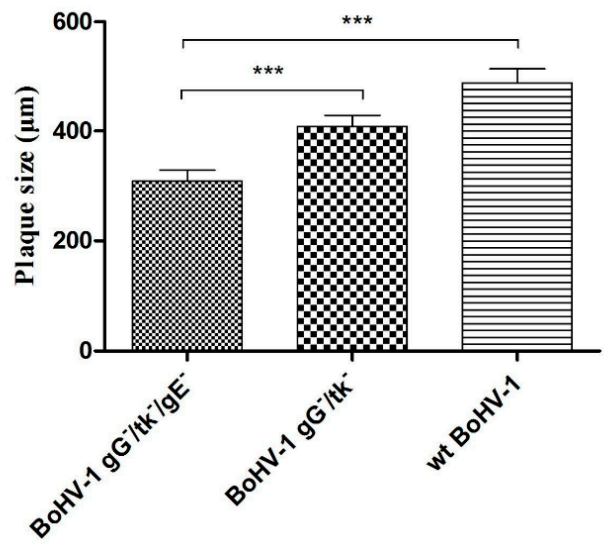

C

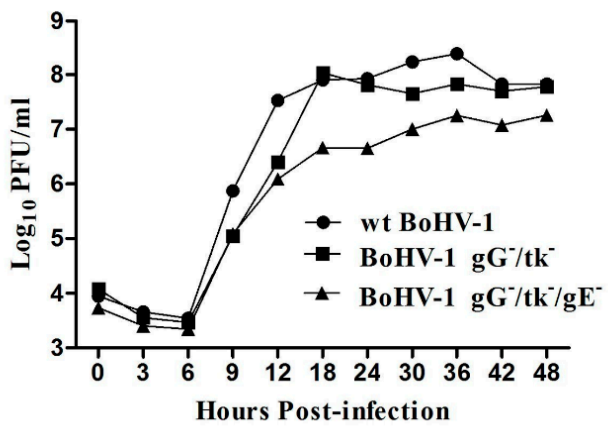

Figure 2. Growth characteristics of BoHV-1 gG-/tk-/gE- compared with wt virus and BoHV-1 gG-/tk- in vitro. (A) Plaque morphology of BoHV-1 gG-/tk-/gE-, BoHV-1 gG-/tk-, and wt BoHV-1 in MDBK cell monolayers. (B) The diameter of 30 plaques for each virus. (C) One-step growth curve of BoHV-1 gG-/tk-/gE- and wt BoHV-1 viruses in MDBK cells. The mark $\left.{ }^{* * *}\right)$ with $p<0.001$ refers to highly significant.

\subsection{Comparative Proteomics of the Three BoHV-1 Strains}

3.3.1. Differentially Expressed Proteins in Different Comparable Strains

A total of 69 protein groups were identified, among which 65 proteins were accurately quantified covering almost all the viral proteins with a quantification ratio consistent in at least two of the three LC-MS/MS analyses (Table S2). Further, the differentially expressed proteins were assessed.

Compared to wt BoHV-1, BoHV-1 gG-tk-gE- triple mutant exhibited downregulation of 16 proteins (namely, gG, TK, gE, gI, gK, DNA replication helicase, BICP4, DNA primase, US1.67, UL7, UL14, UL20, UL41, UL43, UL46, UL51) and upregulation of 12 proteins (gB, gD, UL6, UL24, Triplex capsid protein 1, Triplex capsid protein 2, US3 virion serine/threonine protein kinase, Major capsid protein, Nuclear egress protein 1, Capsid scaffolding protein, Alkaline nuclease, Small capsomere-interacting protein). On the other side, when compared with the double mutant, BoHV-1 gG-tk-gE- triple mutant exhibited 11 downregulated proteins (gE, DNA replication helicase, DNA primase, gI, gK, UL20, UL46, circ protein, virion host shutoff factor, nuclear egress protein 2 and cytoplasmic 
envelopment protein 1) and 24 proteins were upregulated (gB, gC, gD, gL, gM, gN, $\alpha$-TIF, UL3, UL3.5, UL4, UL15, UL43, Vp8, UL50, US1.67, Triplex capsid protein 1, Triplex capsid protein 2, Portal protein, Uracil-DNA glycosylase, BICP0, Major capsid protein, Capsid scaffolding protein, Tripartite terminase subunit 3, Alkaline nuclease, Small capsomereinteracting protein).

Furthermore, the BoHV-1 gG-tk- douple mutant revealed downregulation of 21 proteins (gG, TK, gD, gL, gC, gN, gM, BICP4, Alpha TIF protein, UL3, UL3.5, UL4, UL14, UL15, UL41, UL43, UL46, VP8, UL50, UL51 and US 1.67 protein) and upregulation of one protein only (Major DNA binding protein) when compared to the wt BoHV-1.

Surprisingly, in correlation to the wt BoHV-1, both the double and triple mutants have (a) nine common downregulated proteins (gG, TK, BICP4, UL14, UL41, UL43, UL46, UL51, and US1.67); (b) 12 uniquely upregulated proteins in the double mutant (gC, gD, gL, gM, gN, $\alpha$-TIF, UL3, UL3.5, UL4, UL15, Vp8, and UL50); (c) seven uniquely downregulated in the triple mutant (gE, DNA replication helicase, DNA primase, gI, gK, UL7, and UL20) (Table S3).

\subsubsection{GO Secondary Annotation Classification}

GO classification using the GO Terms Level 2 database was used to examine the traits of the differentially expressed proteins regarding their biological processes (BPs), cellular components (CCs), and molecular functions (MFs) (Figure 3). Comparing the wt BoHV-1 to double mutant BoHV-1 gG-/tk- revealed that most of the proteins were involved in the cellular process (32\%); followed by equal involvement in metabolic process, multi organism process and biological regulation (18\%); then, similar involvement in localization and cellular components organization or biogenesis (5\%) and single organism process (4\%). By cellular components, the classification showed that most of the proteins were located in the membrane (55\%), other organisms (36\%) and virions (9\%). Meanwhile, classification by molecular functions demonstrated that most of the proteins were involved in binding (73\%) and catalytic activity (27\%).

Comparison of wt BoHV-1 to the triple mutant BoHV-1 gG-/tk-/gE- in biological process demonstrated that the differentially expressed proteins were involved in the cellular process (34\%), metabolic process (23\%), multi organism process (19\%); then, equal involvement in biological regulation and cellular components organization or biogenesis $(8 \%)$; similar involvement in locomotion and single organism process $(4 \%)$. By cellular components, the classification showed that most of the proteins belonged to the membrane (41\%), other organisms (30\%), and virions (29\%). By molecular functions, the proteins were involved in binding activity (47\%), catalytic activity (41\%), and structure molecule activity $(12 \%)$.

Finally, comparison of BoHV-1 gG-/tk- to the triple mutant BoHV-1 gG-/tk-/gE- in biological process demonstrated that the differentially expressed proteins were involved in the cellular process $(40 \%)$, multi organism process $(30 \%)$, metabolic process $(20 \%)$, and biological regulation (10\%). By cellular components, the classification showed that most of the proteins were located in the membrane (71\%) and other organisms (29\%). While binding and catalytic activities of differentially expressed proteins shared the half percentage of molecular functions (50\%). 


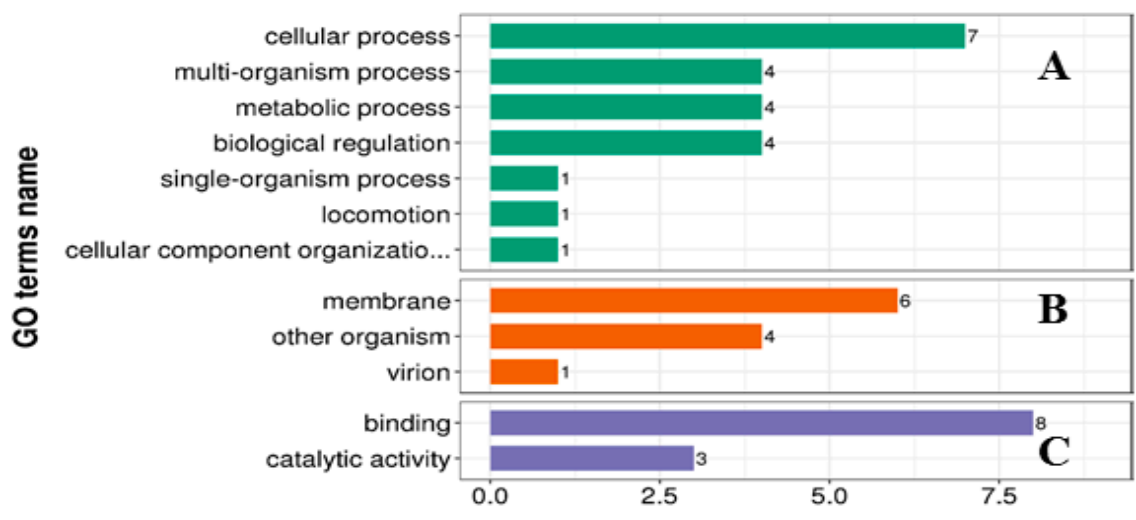

No of proteins ( Wt BoHV-1 Vs double mutant BoHV-1 gG-/tk-)

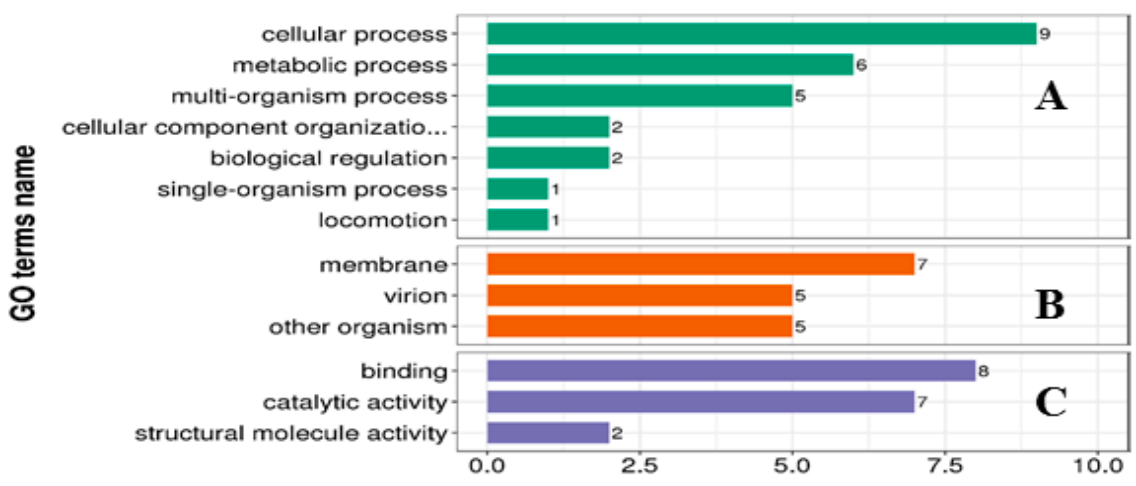

No of proteins (Wt BoHV-1 Vs triple mutant BoHV-1 gG-/tk-/gE-)

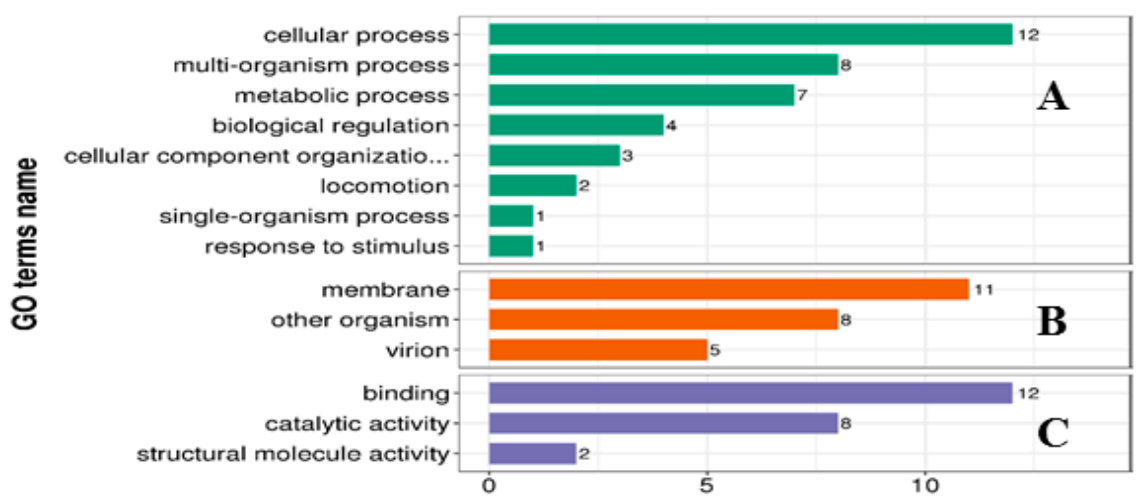

No of proteins (Double mutant BoHV-1 gG-/tk-/gE- vs triple mutant BoHV-1 gG-/tk-/gE-)

A: Biological process (BP) $\quad$ B: Cellular components (CC) $\quad$ C: Molecular function (MF)

Figure 3. Biological process, cellular components, and molecular function categories of proteomic data by bioinformatic analysis of different comparable groups based on information provided by the online resource Gene Ontology, UniProt-GOA database and the InterProScan software. (A) Biological process. (B) Cellular components. (C) Molecular function.

\subsection{In Vivo Experiment Findings}

\subsubsection{Virulence and Reactivation of BoHV-1 gG-/tk-/gE- in Calves}

Following inoculation of calves, BoHV-1 gG-/tk-/gE- did not induce fever (Figure S4A) or clinical signs (Table S4). In contrast, the calves inoculated with wt BoHV-1 displayed clinical signs, including coughing, ocular and nasal discharges, conjunctivitis, depression, 
and abnormal breathing (Table S4), and their clinical scores were significantly higher than that of the other groups $(p<0.001)$ (Figure S4B).

In addition, both mutant-inoculated groups showed significantly less viral shedding $(p<0.001)$ in nasal swabs and shed for a shorter period than the group inoculated with wt BoHV-1 (Table S4 and Figure S4C). The BoHV-1 gG-/tk- inoculated calves shed virus for $6.3 \pm 1.4$ days with a peak viral titer of $10^{2.83} \mathrm{PFU} / \mathrm{mL}$ at $4 \mathrm{dpi}$, whereas the BoHV-1 gG-/tk-/gE- inoculated calves shed virus only for $3.5 \pm 0.8$ days, with a peak viral titer of $10^{2.04} \mathrm{PFU} / \mathrm{mL}$ at $4 \mathrm{dpi}$, and showed significantly less viral shedding $(p<0.001)$ than the former group (Figure S4C).

Neither the BoHV-1 gG-/tk-/gE- nor the BoHV-1 gG-/tk- mutant could be reactivated by dexamethasone injection in calves. However, the wt BoHV-1 was detected in nasal swabs 1-3 days after the dexamethasone injection (Figure S4C)

\subsubsection{Protection of BoHV-1 gG-/tk-/gE- against wt BoHV-1 Challenge in Calves}

To evaluate the protective efficacy of BoHV-1 gG-/tk-/gE- against wt BoHV-1 challenge, three calves from each group were challenged with wt BoHV-1. Two calves in BoHV-1 gG-/tk-/gE- inoculated group and one calf in BoHV-1 gG-/tk- inoculated group experienced fever $\left(>39.7^{\circ} \mathrm{C}\right)$. All calves in the unvaccinated control group had elevated temperatures above $40^{\circ} \mathrm{C}$ for 3 days (Figure $4 \mathrm{~A}$ ). The number of days of fever, ocular and nasal lesions, and cough are presented in Table S5. The clinical scores recorded after the challenge are shown in Figure 4B. One of three calves in both mutant vaccinated groups displayed clinical signs with a score of more than 3 after the challenge. All calves in the unvaccinated control group displayed fever, nasal and ocular discharge, cough, and conjunctivitis. As a result, their clinical scores were significantly increased after the challenge (Figure 4B). The negative control group did not display any abnormal clinical signs.

The calves in BoHV-1 gG-/tk-/gE- inoculated group shed virus for $9.3 \pm 1.1$ days, with a peak viral titer of $10^{4.18} \mathrm{PFU} / \mathrm{mL}$ at day $5 \mathrm{dpc}$. Compared to the BoHV- $1 \mathrm{gG}-/ \mathrm{tk}-$ /gE- inoculated group, calves in the BoHV-1 gG-/tk-inoculated group shed the virus for a shorter period (6.0 \pm 1.0 days) with a peak viral titer of $10^{3.18} \mathrm{PFU} / \mathrm{mL}$ at $5 \mathrm{dpc}$ with less, although not significant, viral shedding $(p>0.05)$. The unvaccinated calves shed virus for $11.3 \pm 1.5$ days with a peak viral titer of $10^{5.32} \mathrm{PFU} / \mathrm{mL}$ at $5 \mathrm{dpc}$ (Table S5), which was significantly higher $(p<0.01)$ than those of both groups of mutant vaccination (Figure $4 \mathrm{C})$.

The mean score for lung pathology per calf for the BoHV-1 gG-/tk-/gE-, BoHV-1 gG/tk-, unvaccinated but challenged, and blank control groups was $6.00 \pm 3.00$, $2.67 \pm 2.08,13.33 \pm 3.06$, and $2.00 \pm 1.00$, respectively (Figure $4 \mathrm{D}$ ). The mean score of the unvaccinated group was significantly higher than those of the other groups $(p<0.01)$.

The protection rates were calculated based on the totals of the various scoring systems (Table S6). The overall protection rate for the BoHV-1 gG-/tk-/gE- and BoHV-1 gG-/tkgroup was $91.7 \%$ and $64.2 \%$, respectively. 

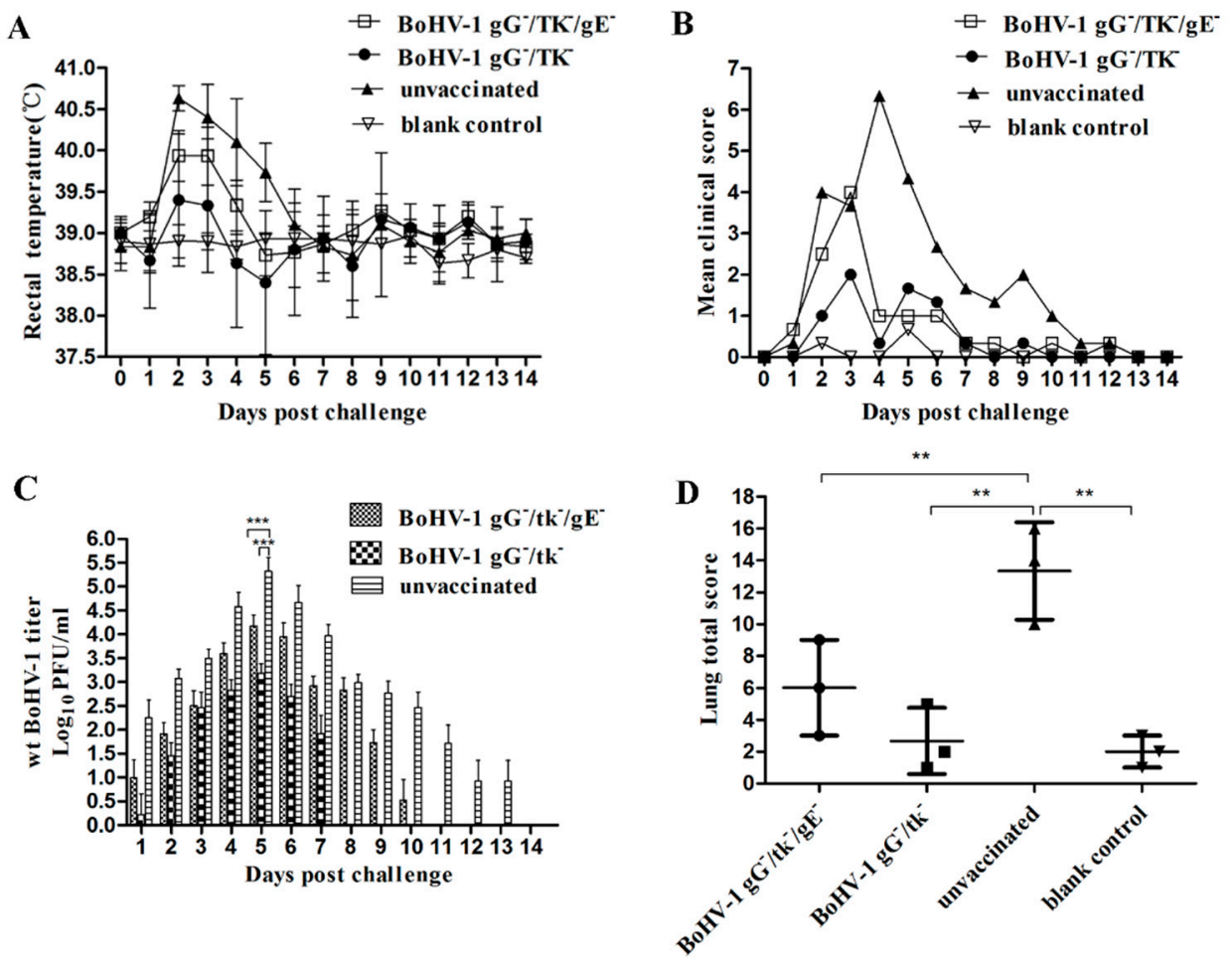

Figure 4. Protective efficacy of BoHV-1 gG-/tk-/gE- against wt BoHV-1 (A-D) challenge in calves. (A) Temperature change. (B) Clinical scores. (C) Nasal virus shedding. (D) Lesion scores of lungs. The mark (**) with $p<0.01$ and $\left(^{* * *}\right)$ with $p<0.001$ were considered to indicate a significant or high significant statistical difference respectively.

\subsubsection{Cross-Protection of BoHV-1 gG-/tk-/gE- against wt BoHV-5 Challenge in Calves}

To check whether vaccination with BoHV-1 gG-/tk-/gE- or BoHV-1 gG-/tk- could induce cross-protection to BoHV-5 infections, three calves from each group were challenged with wt BoHV-5 strain. After challenge, one calf in both groups (BoHV-1 gG/tk-/gE- and BoHV-1 gG-/tk-) experienced fever $\left(>39.7^{\circ} \mathrm{C}\right)$ for 1 day. In contrast, two calves in the unvaccinated group had a temperature above $40{ }^{\circ} \mathrm{C}$ for 3 and 4 days, respectively (Figure 5A). Respiratory signs detected in both mutant-inoculated groups were less severe and remained for a shorter period than those observed in unvaccinated animals (Table S5). The clinical scores recorded after the challenge are shown in Figure 5B. Neurological signs including head-pressing were observed in one calf of the BoHV-1 gG/tk-/gE- inoculated group for 3 consecutive days (8-10 dpc) and in one calf of the BoHV-1 $\mathrm{gG}-/$ tk- inoculated group for 1 day $(7 \mathrm{dpc})$, while head-pressing was observed in two calves of the unvaccinated groups for 3 consecutive days.

Unvaccinated calves shed virus for $12.0 \pm 1.7$ days with a peak shedding at $6 \mathrm{dpc}$ $\left(10^{4.06} \mathrm{PFU} / \mathrm{mL}\right)$. However, the viral shedding in BoHV-1 gG-/tk-/gE- and BoHV-1 gG-/tkinoculated groups was observed for $9.3 \pm 1.5$ and $8.0 \pm 1.0$ days, respectively. The peak viral titer of BoHV-1 gG-/tk-/gE- and BoHV-1 gG-/tk- was $10^{3.25}$ (6 dpc) and $10^{2.88} \mathrm{PFU} / \mathrm{mL}$ (4 dpc), respectively (Table S5). In addition, viral titers shed from the BoHV- $1 \mathrm{gG}-/ \mathrm{tk}-$ /gE- and BoHV-1 gG-/tk- inoculated groups were significantly lower than that of the unvaccinated group at $6 \mathrm{dpc}$ (BoHV-1 gG-/tk-/gE- vs. unvaccinated: $p<0.05$, BoHV-1 gG-/tk- vs. unvaccinated: $p<0.01$ ) (Figure $5 \mathrm{C}$ ).

The mean score for lung pathology for the BoHV-1 gG-/tk-/gE-, BoHV-1 gG-/tk-, unvaccinated but challenged, and blank control groups was $6.00 \pm 4.58,9.00 \pm 6.00$, $15.33 \pm 7.57$, and $2.00 \pm 1.00$, respectively (Figure 5D). The mean score for the unvaccinated group was higher than that of the blank control group $(p<0.05)$ but without significant differences while compared with that of the other groups. 
The protection rates were calculated based on the total scores of the various scoring systems (Table S6). The overall protection rate for the BoHV-1 gG-/tk-/gE- and BoHV-1 gG-/tk- group was $68.6 \%$ and $47.22 \%$, respectively.

A

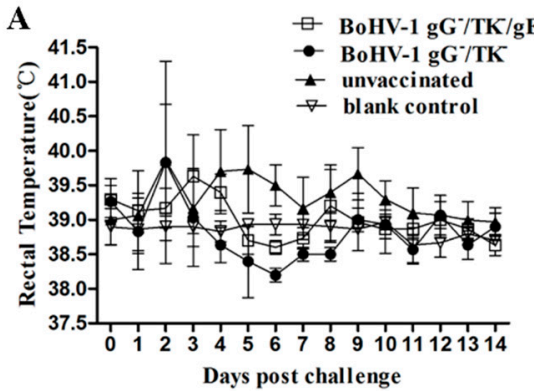

C

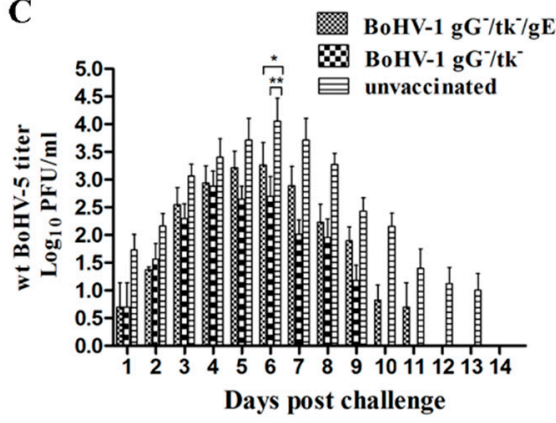

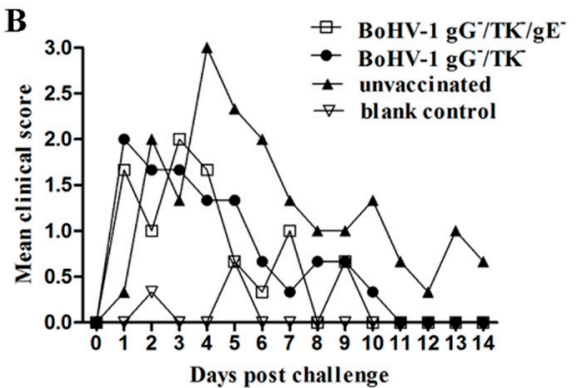

D

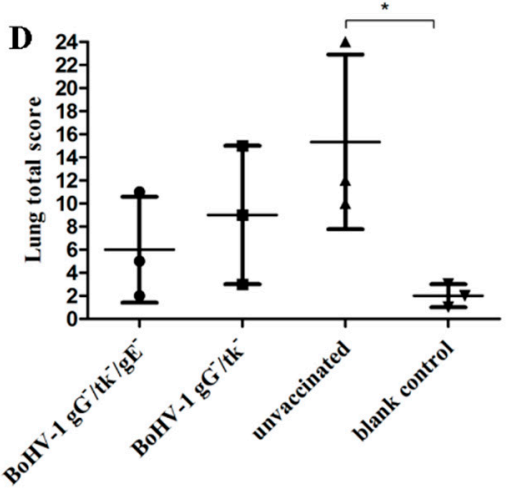

Figure 5. Protective efficacy of BoHV-1 gG-/tk-/gE- against wt BoHV-5 (A-D) challenge in calves. (A) Temperature change. (B) Clinical scores. (C) Nasal virus shedding. (D) Lesion scores of lungs. The mark $\left(^{*}\right)$ with $p<0.05$ and $\left(^{* *}\right)$ with $p<0.01$ were considered to indicate a significant difference.

\subsection{Serological Investigations}

\subsubsection{Humoral Immune Response in Calves}

The serum samples obtained at intervals after vaccination and challenge were tested for VN antibody (Figure S5). Two of the six calves in the BoHV-1 gG-/tk-/gE- inoculated group were positive for $\mathrm{VN}$ antibody at $28 \mathrm{dpi}$, and four calves were positive at $35 \mathrm{dpi}$. In contrast, two of six calves in the BoHV-1 gG-/tk-inoculated group were positive at $14 \mathrm{dpi}$ and five calves were positive at $21 \mathrm{dpi}$. In addition, there were significantly lower $(p<0.01) \mathrm{VN}$ antibody titers in the BoHV-1 gG-/tk-/gE- inoculated calves $(0.8 \pm 1.3)$ than in the BoHV-1 gG-/tk- inoculated group $(6.0 \pm 4.5)$ at 28 dpi (Figure S5A) Interestingly, following the wt BoHV-1 challenge, a strong and rapid increase of VN antibody titers was observed in both inoculated groups. Similarly, the titers in the BoHV-1 $\mathrm{gG}-/ \mathrm{tk}-/ \mathrm{gE}$ - inoculated group increased, although the titers were significantly lower $(p<0.01)$ at 56 dpi when compared to the BoHV-1 gG-/tk- inoculated group (Figure S5B). Moreover, following wt BoHV-5 challenge, the calves in both the mutant-inoculated groups developed VN antibodies to BoHV-1 (Figure S5C) and BoHV-5 (Figure S5D), and the BoHV-1 gG-/tk-/gE- inoculated group also had similar increases when compared to the BoHV-1 gG-/tk- inoculated group. Further, both mutant-inoculated groups developed $\mathrm{VN}$ antibodies with no significant differences in $\mathrm{VN}$ antibody titers to wt BoHV-1 virus (Figure S5C) and wt BoHV-5 virus (Figure S5D) after wt BoHV-5 challenge. In contrast, the unvaccinated control calves developed a lower and delayed antibody response after challenge, which were typical of primary responses.

Sera from all calves of the BoHV-1 gG-/tk- and wt BoHV-1 inoculated groups had positive ( $\geq 55 \%$ ) anti-BoHV-1 gB antibodies at $14 \mathrm{dpi}$, while $21 \mathrm{dpi}$ for BoHV-1 gG-/tk-/gEinoculated group (Figure S6A). Groups that were BoHV-1 gG-/tk- vaccinated or wt BoHV-1 infected were found to be positive for gE-specific antibodies at $21 \mathrm{dpi}$. However, no anti-gE 
antibody was detected in all calves of the BoHV-1 gG-/tk-/gE- inoculated group before the challenge (Figure S6B).

IgA increased in the sera of BoHV-1 gG-/tk-/gE- inoculated calves after vaccination, although this was not significantly different from that of the BoHV-1 gG-/tk- and wt BoHV-1 inoculated groups (Figure S6C).

\subsubsection{Cytokine Production in Calves}

IFN- $\gamma$ was detected but none of the BoHV-1 mutant vaccinated groups generated a significant increase in the level (Figure S7). IL-2 was not detectable from any calf. IL-4 was detected in all calves of the BoHV-1 gG-/tk- inoculated group at $1 \mathrm{dpi}$, whereas in the BoHV-1 gG-/tk-/gE- inoculated group only two calves were detectable after vaccination (Table S7), and the level was significantly lower $(p<0.05)$ than that of the BoHV-1 gG/tk- inoculated group at $14 \mathrm{dpi}$. However, none of the wt BoHV-1 infection groups were detectable in IL-4 after infection.

\section{Discussion}

Vaccination is an effective control measure against IBR. Several European countries have initiated control programs aimed at BoHV-1 eradication based on the use of marker vaccines [26]. These marker vaccines have one or more antigenic proteins less than the parental wt virus, and it is possible to detect an antibody response to the specific deleted protein which could allow differentiation of infected from vaccinated animals [27].

To diminish the pathogenicity and avoid virus recombination, triple mutant BoHV-1 $\mathrm{gG}-/ \mathrm{tk}-/ \mathrm{gE}-$ was developed on the base of the double mutant vaccinal strain BoHV-1 $\mathrm{gG}-/ \mathrm{tk}$ as a superior vaccine candidate [28]. On the other side, LFQP helps control viral infectious disease affecting cattle via identification of virion-associated proteins and it can translate the basic science investigations into practical measures $[29,30]$.

The BoHV-1 gG-/tk-/gE- mutant exhibited growth kinetics inferior to that of wt BoHV-1, and double mutant gG-/tk- with smaller plaques of uncleared edges and reduced sizes observed during the in vitro study. Moreover, it showed a significantly lower virus shedding and shorter period of shedding in vivo. Therefore, BoHV-1 gG-/tk-/gE- exhibited more attenuation and less virulence in vivo and in vitro which might be attributed to missing the key role of $\mathrm{gE}$ in cell-to-cell spread of the virus in cultured cells and virulence [31-34].

From a proteomic point of view, the GO classification was mainly involved in the cellular process and the metabolic process by BPs belongs to membrane part by CPs and exhibited binding and catalytic activities by MFs. This attributed to the virion assembly of gG and gE as a membrane envelope protein and their role in cell-to-cell spread, cell attachment, and chemokine binding function as well as the crucial effect of tk as a virulencerelated gene $[18,19]$.

The BoHV-1 gG-/tk-/gE- mutant appeared to be immunogenic and less virulent comparing to other virions due to the deletion of virulence-related genes ( $\mathrm{t} k$ and $\mathrm{gE}$ ) and immunosuppressive gG $[19,35]$. These results indicate the triple gene deleted virions lost the greatest part of its virulence comparing to the other two virions with retaining its immunogenicity [17,36-38].

After BoHV-1 challenge, the BoHV-1 gG-/tk-/gE- could still protect against virulent wt BoHV-1 challenge even though it was more attenuated. However, the protection against virulent BoHV-1 challenge of BoHV-1 gG-/tk-/gE- was lower than that of BoHV-1 gG-/tksince the calves inoculated with BoHV-1 gG-/tk-/gE- show higher clinical scores, a shorter period of virus shedding. The reason for lower protection might be that the immunogenicity of BoHV-1 strains is directly related to their replication efficiency in vivo [39]. Hence, gene deletions for attenuation may affect replication and, consequently, compromise the immunogenicity [40]. Thus, it is expected that the low virulence strain of triple mutant induces a lower immune response ( $\mathrm{VN}$ antibody and gB-specific antibody), a delay in the production of $\mathrm{VN}$ antibody, and had lower protection rates than the double mutant. 
Although no cases of neurological disease caused by BoHV-5 have been reported in China, they have been reported in Europe, the USA, and Australia [41]. However, the increasing importance of China's cattle industry in the global beef market will probably lead to an increasing number of international trades of cattle and products, which may lead to the entry of BoHV-5 accidentally through animal imports. Therefore, there is a dire need for the development of safer and more effective vaccines against BoHV-5 infection. Previous work in calves suggested that subcutaneous inoculation of either BoHV-1 or BoHV-5 vaccines conferred partial protection to the BoHV-5 challenge [40,42,43]. Given the fact, we checked whether vaccination with BoHV-1 gG-/tk-/gE- and BoHV-1 gG-/tkwould induce cross-protection to BoHV-5 infections. In both groups of mutant-inoculated calves, only partial protection was attained. Nasal BoHV-5 shedding post-challenge was not significantly reduced by vaccination except at $6 \mathrm{dpc}$. Vaccination also did not fully prevent the development of neurological signs in calves after challenge. However, unvaccinated calves developed more pronounced neurological signs. As a result, both mutants provided insufficient protection to the BoHV-5 challenge, similar to that reported by others [43].

Based on the previous reports regarding the IBR marker vaccine [15] and as elucidated above, the triple mutant BoHV-1 gG-/tk-/gE- may serve as a candidate marker vaccine for controlling BoHV-1 infection in the cattle industry.

\section{Conclusions}

BoHV-1 gG-/tk-/gE- could be a safer candidate marker vaccine against IBR and booster vaccination might be an effective approach to increase the immune response against the challenge, but this requires further investigation. Moreover, the comparative proteomic analysis revealed dysregulation of some unique proteins in this triple mutant BoHV-1 gG-/tk-/gE- and double mutant BoHV-1 gG-/tk- correlated to the wt BoHV-1 that can be used as diagnostic biomarkers.

Supplementary Materials: The following are available online at https:/ /www.mdpi.com/article/10 .3390 /vetsci8110253/s1, Figure S1. Construction strategy of pBoHV-1 gE- and recombinant BoHV-1 gG-/tk-/gE- viruses based on BoHV-1 gG-/tk- mutant. (A) Construction of transfer vector, including target deletion region, upstream, downstream fragments and inserted EGFP expression cassette. (B) BoHV-1 gG-/tk- genome. (C) BoHV-1 gG-/tk-/gE- genome. The gE gene was deleted by insertion of EGFP expression cassette. Figure S2. General workflow for the purification of the four different virions of BoHV-1 and mass spectrometry steps of LC.MS/MS. (A) Extracellular virions were purified using centrifugation/ultracentrifugation method on sucrose density gradient cushion. As the step of purity of crucial importance, EM observation is carried out to confirm the purity of the virions and absence of cell debris. Contaminating proteins were removed by the proteolysis of purified virions. (B) Analysis of virion-associated protein composition by mass spectrometry. Typical steps for analyzing virion-associated proteins by LC-MS/MS of extracted proteins of purified virions and separated proteins of purified virions using $1 \mathrm{D}$ gel electrophoresis. Finally, database search and bioinformatic analysis were performed. Figure S3. Quality Control (QC) Validation of MS Data; (A) peptide mass tolerance distribution (B) identified peptide length distribution (C) protein mass and coverage distribution. Figure S4. Clinical signs and reactivation of BoHV-1 mutant in calves. Temperature change (A), Mean daily clinical score (B), and nasal virus shedding (C) in calves following vaccination with BoHV-1 gG-/tk-/gE-, BoHV-1 gG-/tk- and wt BoHV-1 and after dexamethasone injection. Clinical signs combining body temperature, behavior, presence of coughs, abnormal respiration, ocular and nasal discharges, hyperemia, or lesions of the nasal mucosa, and conjunctivitis were scored as described earlier [1]. Nasal virus shedding was detected as described below: nasal swabs were submitted for virus isolation and quantitation. The nasal swab medium was filtered through $0.22 \mu \mathrm{m}$ filters before being inoculated into MDBK cell cultures in 24-well tissue culture plates. The plates were monitored daily for characteristic BoHV cytopathic effects (CPE) for up to 4 days. The infectivity of the samples positive to the virus was subsequently quantified by plaque assay on MDBK cells in 24-well cell culture plates as described previously [2]. Figure S5. Virus-neutralizing (VN) antibodies titers in calves. Virus-neutralizing (VN) antibodies against BoHV-1 following vaccination (A) and challenge with wt BoHV-1 (B) or wt BoHV-5 (C). VN antibodies against BoHV-5 after challenge with wt BoHV-5 (D). VN antibodies were examined in a varying serum-constant virus neutralization (SN) 
assay in 96-well plates, with two-fold dilutions of serum against 100 TCID50 of either BoHV-1 strain HB06 or BoHV-5 strain EVI 88/95. The VN titers were expressed as the reciprocal of the highest serum dilution that prevented the development of cytopathic effect (CPE) after $72 \mathrm{~h}$ of incubation at $37^{\circ} \mathrm{C}$. Figure S6. Antibody ELISA assays. Anti-BoHV-1 gB antibody (A), gE antibody (B), and serum sIgA (C) were determined in serum from vaccinated animals at different dpi. Serum samples with blocking $\%$ of $55 \%$ and greater are considered positive for BoHV-1 gB antibodies. Serum samples with an $\mathrm{S} / \mathrm{N}$ ratio of 0.60 and lower are considered positive for BoHV-1 gE antibodies. Figure S7. IFN- $\gamma$ detection after vaccination. Table S1. The primers used in this study. Table S2. The total identified virion proteins of the three strains after LC-MS/MS peptides identification and database search using UNIPROT. Table S3. Comparative upregulated and downregulated proteins detected in wt BoHV-1, double mutant BoHV-1 gG-/tk-, and the triple mutant BoHV-1 gG-/tk-/gE-. Table S4. Mean number of days of fever, ocular and nasal lesions, cough, and nasal virus shedding after intranasal inoculation. Table S5. Mean number of days of fever, ocular and nasal lesions, cough, and nasal virus shedding after challenge. Table S6. Assessment of protection rates based on different scoring systems. Table S7. IL-4 detection after vaccination.

Author Contributions: M.A.M., conceptualization, revising, data curation, and most of methodology; M.D., formal analysis, drafting and part of methodology; C.W., part of methodology, analysis of data, drafting, and validation; Y.C., resources, investigation, and validation; C.H., visualization, validation, data analysis, and revision; J.C., visualization, experimental design, drafting, and review editing; X.C., software, computation, statistical analysis, and review editing; H.C., writing-review and editing, revision, investigation and validation of the in vitro study; A.G., developed the theory, supervision, revision, and review of the final version for submission. All authors have read and agreed to the published version of the manuscript.

Funding: This work was funded by the China Agriculture Research System (Beef/Yaks) of MOF and MARA(CARS-37) and Key Research and Development Program of the Ningxia Hui Autonomous Region (\# 2021BEF02028).

Institutional Review Board Statement: The protocols regarding animal experiment \#HZAURAB2019-006 for calves were approved by the committee on the ethics of animal experiments at Huazhong Agriculture University and were conducted in strict accordance with the guide for the care and use of laboratory animals, Hubei Province, China.

Informed Consent Statement: Not applicable.

Data Availability Statement: Data sharing not applicable.

Acknowledgments: We thank the Agro-Scientific Research in the Public Interest, Higher Education in china and China Agriculture Research System (Beef/Yak Cattle).

Conflicts of Interest: The authors declare no conflict of interest.

\section{References}

1. Biswas, S.; Bandyopadhyay, S.; Dimri, U.; Patra, P.H. Bovine herpesvirus-1 (BHV-1)-a re-emerging concern in livestock: A revisit to its biology, epidemiology, diagnosis, and prophylaxis. Vet. Q. 2013, 33, 68-81. [CrossRef] [PubMed]

2. Engel, E.A.; Song, R.; Koyuncu, O.O.; Enquist, L.W. Investigating the biology of alpha herpesviruses with MS-based proteomics. Proteomics 2015, 15, 1943-1956. [CrossRef]

3. Muylkens, B.; Thiry, J.; Kirten, P.; Schynts, F.; Thiry, E. Bovine herpesvirus 1 infection and infectious bovine rhinotracheitis. Vet. Res. 2007, 38, 181-209. [CrossRef]

4. D'Arce, R.C.; Almeida, R.S.; Silva, T.C.; Franco, A.C.; Spilki, F.; Roehe, P.M.; Arns, C.W. Restriction endonuclease and monoclonal antibody analysis of Brazilian isolates of bovine herpesviruses types 1 and 5. Vet. Microbiol. 2002, 88, 315-324. [CrossRef]

5. Jones, C. Bovine Herpesvirus 1 Counteracts Immune Responses and Immune-Surveillance to Enhance Pathogenesis and Virus Transmission. Front. Immunol. 2019, 10, 1008. [CrossRef]

6. Silvestro, C.; Bratanich, A. The latency related gene of bovine herpesvirus types 1 and 5 and its modulation of cellular processes. Arch. Virol. 2016, 161, 3299-3308. [CrossRef]

7. Guo, J.; Li, Q.; Jones, C. The bovine herpesvirus 1 regulatory proteins, bICP4 and bICP22, are expressed during the escape from latency. J. Neurovirol. 2019, 25, 42-49. [CrossRef] [PubMed]

8. Petrini, S.; Iscaro, C.; Righi, C. Antibody Responses to Bovine Alphaherpesvirus 1 (BoHV-1) in Passively Immunized Calves. Viruses 2019, 11, 23. [CrossRef] 
9. Robinson, K.E.; Meers, J.; Gravel, J.L.; McCarthy, F.M.; Mahony, T.J. The essential and non-essential genes of Bovine herpesvirus 1. J. Gen. Virol. 2008, 89, 2851-2863. [CrossRef]

10. Van Engelenburg, F.A.; Kaashoek, M.J.; van Oirschot, J.T.; Rijsewijk, F.A. A glycoprotein E deletion mutant of bovine herpesvirus 1 infects the same limited number of tissues in calves as wild-type virus, but for a shorter period. J. Gen. Virol. 1995, 76 Pt 9 , 2387-2392. [CrossRef]

11. Strube, W.; Auer, S.; Block, W.; Heinen, E.; Kretzdorn, D.; Rodenbach, C.; Schmeer, N. A gE deleted infectious bovine rhinotracheitis marker vaccine for use in improved bovine herpesvirus 1 control programs. Vet. Microbiol. 1996, 53, 181-189. [CrossRef]

12. Kaashoek, M.J.; van Engelenburg, F.A.; Moerman, A.; Gielkens, A.L.; Rijsewijk, F.A.; van Oirschot, J.T. Virulence and immunogenicity in calves of thymidine kinase- and glycoprotein E-negative bovine herpesvirus 1 mutants. Vet. Microbiol. 1996, 48, 143-153. [CrossRef]

13. Van Engelenburg, F.A.; Kaashoek, M.J.; Rijsewijk, F.A.; van den Burg, L.; Moerman, A.; Gielkens, A.L.; van Oirschot, J.T. A glycoprotein E deletion mutant of bovine herpesvirus 1 is avirulent in calves. J. Gen. Virol. 1994, 75 Pt 9, 2311-2318. [CrossRef]

14. Belknap, E.B.; Walters, L.M.; Kelling, C.; Ayers, V.K.; Norris, J.; McMillen, J.; Hayhow, C.; Cochran, M.; Reddy, D.N.; Wright, J.; et al. Immunogenicity and protective efficacy of a gE, gG and US2 gene-deleted bovine herpesvirus-1 (BHV-1) vaccine. Vaccine 1999, 17, 2297-2305. [CrossRef]

15. Chowdhury, S.I.; Wei, H.; Weiss, M.; Pannhorst, K.; Paulsen, D.B. A triple gene mutant of BoHV-1 administered intranasally is significantly more efficacious than a BoHV-1 glycoprotein E-deleted virus against a virulent BoHV-1 challenge. Vaccine 2014, 32 , 4909-4915. [CrossRef] [PubMed]

16. Nunez Villavicencio-Diaz, T.; Rodríguez-Ulloa, A.; Guirola-Cruz, O.; Perez-Riverol, Y. Bioinformatics tools for the functional interpretation of quantitative proteomics results. Curr. Top. Med. Chem. 2014, 14, 435-449. [CrossRef]

17. Zhang, M.; Fu, S.; Deng, M.; Xie, Q.; Xu, H.; Liu, Z.; Hu, C.; Chen, H.; Guo, A. Attenuation of bovine herpesvirus type 1 by deletion of its glycoprotein $G$ and tk genes and protection against virulent viral challenge. Vaccine 2011, 29, 8943-8950. [CrossRef] [PubMed]

18. Barber, K.; Daugherty, H.; Ander, S.; Jefferson, V.; Shack, L.; Pechan, T.; Nanduri, B.; Meyer, F. Protein composition of the bovine herpesvirus 1.1 virion. Vet. Sci. 2017, 4, 11. [CrossRef]

19. Al-Mubarak, A.; Simon, J.; Coats, C.; Okemba, J.D.; Burton, M.D.; Chowdhury, S.I. Glycoprotein E (gE) specified by bovine herpesvirus type 5 (BHV-5) enables trans-neuronal virus spread and neurovirulence without being a structural component of enveloped virions. J. Virol. 2007, 365, 398-409. [CrossRef]

20. Du, Y.; Cai, T.; Li, T.; Xue, P.; Zhou, B.; He, X.; Wei, P.; Liu, P.; Yang, F.; Wei, T. Lysine malonylation is elevated in type 2 diabetic mouse models and enriched in metabolic associated proteins. Mol. Cell. Proteom. 2015, 14, 227-236. [CrossRef]

21. Valera, A.R.; Pidone, C.L.; Massone, A.R.; Quiroga, M.A.; Riganti, J.G.; Corva, S.G.; Galosi, C.M. A simple method of infecting rabbits with Bovine herpesvirus 1 and 5. J. Virol. Methods 2008, 150, 77-79. [CrossRef] [PubMed]

22. Wei, H.; He, J.; Paulsen, D.B.; Chowdhury, S.I. Bovine herpesvirus type 1 (BHV-1) mutant lacking U(L)49.5 luminal domain residues 30-32 and cytoplasmic tail residues 80-96 induces more rapid onset of virus neutralizing antibody and cellular immune responses in calves than the wild-type strain Cooper. Vet. Immunol. Immunopathol. 2012, 147, 223-229. [CrossRef]

23. Chowdhury, S.I. Construction and characterization of an attenuated bovine herpesvirus type 1 (BHV-1) recombinant virus. Vet. Microbiol. 1996, 52, 13-23. [CrossRef]

24. Vordermeier, H.M.; Villarreal-Ramos, B.; Cockle, P.J.; McAulay, M.; Rhodes, S.G.; Thacker, T.; Gilbert, S.C.; McShane, H.; Hill, A.V.; Xing, Z. Viral booster vaccines improve Mycobacterium bovis BCG-induced protection against bovine tuberculosis. Infect. Immun. 2009, 77, 3364-3373. [CrossRef]

25. Zhang, R.; Han, X.; Chen, Y.; Mustafa, R.; Qi, J.; Chen, X.; Hu, C.; Chen, H.; Guo, A. Attenuated Mycoplasma bovis strains provide protection against virulent infection in calves. Vaccine 2014, 32, 3107-3114. [CrossRef]

26. Ackermann, M.; Engels, M. Pro and contra IBR-eradication. Vet. Microbiol. 2006, 113, 293-302. [CrossRef]

27. Uddowla, S.; Hollister, J.; Pacheco, J.M.; Rodriguez, L.L.; Rieder, E. A safe foot-and-mouth disease vaccine platform with two negative markers for differentiating infected from vaccinated animals. J. Virol. 2012, 86, 11675-11685. [CrossRef] [PubMed]

28. Jones, C.; Chowdhury, S. A review of the biology of bovine herpesvirus type 1 (BHV-1), its role as a cofactor in the bovine respiratory disease complex and development of improved vaccines. Anim. Health Res. Rev. 2007, 8, 187-205. [CrossRef]

29. Rho, J.H.; Qin, S.; Wang, J.Y.; Roehrl, M.H. Proteomic expression analysis of surgical human colorectal cancer tissues: Upregulation of PSB7, PRDX1, and SRP9 and hypoxic adaptation in cancer. J. Proteome Res. 2008, 7, 2959-2972. [CrossRef]

30. Alfonso, P.; Núñez, A.; Madoz-Gurpide, J.; Lombardia, L.; Sánchez, L.; Casal, J.I. Proteomic expression analysis of colorectal cancer by two-dimensional differential gel electrophoresis. Proteomics 2005, 5, 2602-2611. [CrossRef]

31. Chowdhury, S.I.; Ross, C.S.; Lee, B.J.; Hall, V.; Chu, H.J. Construction and characterization of a glycoprotein E gene-deleted bovine herpesvirus type 1 recombinant. Am. J. Vet. Res. 1999, 60, 227-232.

32. Schwyzer, M.; Ackermann, M. Molecular virology of ruminant herpesviruses. Vet. Microbiol. 1996, 53, 17-29. [CrossRef]

33. Muylkens, B.; Meurens, F.; Schynts, F.; Farnir, F.; Pourchet, A.; Bardiau, M.; Gogev, S.; Thiry, J.; Cuisenaire, A.; Vanderplasschen, A.; et al. Intraspecific bovine herpesvirus 1 recombinants carrying glycoprotein E deletion as a vaccine marker are virulent in cattle. J. Gen. Virol. 2006, 87, 2149-2154. [CrossRef]

34. Kaashoek, M.J.; Moerman, A.; Madic, J.; Rijsewijk, F.A.; Quak, J.; Gielkens, A.L.; van Oirschot, J.T. A conventionally attenuated glycoprotein E-negative strain of bovine herpesvirus type 1 is an efficacious and safe vaccine. Vaccine 1994, 12, 439-444. [CrossRef] 
35. Shaw, A.; Braun, L.; Frew, T.; Hurley, D.; Rowland, R.; Chase, C. A role for bovine herpesvirus 1 (BHV-1) glycoprotein E (gE) tyrosine phosphorylation in replication of BHV-1 wild-type virus but not BHV-1 gE deletion mutant virus. Virology 2000, 268, 159-166. [CrossRef] [PubMed]

36. Petrini, S.; Righi, C.; Iscaro, C.; Viola, G.; Gobbi, P.; Scoccia, E.; Rossi, E.; Pellegrini, C.; De Mia, G.M. Evaluation of Passive Immunity Induced by Immunisation Using Two Inactivated gE-deleted Marker Vaccines against Infectious Bovine Rhinotracheitis (IBR) in Calves. Vaccines 2020, 8, 14. [CrossRef]

37. Ampe, B.; Duchateau, L.; Speybroeck, N.; Berkvens, D.; Dupont, A.; Kerkhofs, P.; Thiry, E.; Dispas, M. Assessment of the long-term effect of vaccination on transmission of infectious bovine rhinotracheitis virus in cattle herds hyperimmunized with glycoprotein E-deleted marker vaccine. Am. J. Vet. Res. 2012, 73, 1787-1793. [CrossRef] [PubMed]

38. El-Kholy, A.A.; Rady, D.I.; Abdou, E.R.; Elseafy, M.M.; Abdelrahman, K.A.; Soliman, H. Construction, characterization and immunogenicity of a glycoprotein E negative bovine herpesvirus-1.1 Egyptian strain "Abu-Hammad". J. Virol. Methods 2013, 194, 74-81. [CrossRef]

39. Kaashoek, M.J.; Moerman, A.; Madic, J.; Weerdmeester, K.; Maris-Veldhuis, M.; Rijsewijk, F.A.; van Oirschot, J.T. An inactivated vaccine based on a glycoprotein E-negative strain of bovine herpesvirus 1 induces protective immunity and allows serological differentiation. Vaccine 1995, 13, 342-346. [CrossRef]

40. Anziliero, D.; Santos, C.M.; Brum, M.C.; Weiblen, R.; Chowdhury, S.I.; Flores, E.F. A recombinant bovine herpesvirus 5 defective in thymidine kinase and glycoprotein $\mathrm{E}$ is immunogenic for calves and confers protection upon homologous challenge and BoHV-1 challenge. Vet. Microbiol. 2011, 154, 14-22. [CrossRef]

41. Del Medico Zajac, M.P.; Ladelfa, M.F.; Kotsias, F.; Muylkens, B.; Thiry, J.; Thiry, E.; Romera, S.A. Biology of bovine herpesvirus 5. Vet. J. 2010, 184, 138-145. [CrossRef] [PubMed]

42. Del Medico Zajac, M.P.; Puntel, M.; Zamorano, P.I.; Sadir, A.M.; Romera, S.A. BHV-1 vaccine induces cross-protection against BHV-5 disease in cattle. Res. Vet. Sci. 2006, 81, 327-334. [CrossRef] [PubMed]

43. Silva, A.D.; Spilki, F.R.; Franco, A.C.; Esteves, P.A.; Hubner, S.O.; Driemeier, D.; Oliveira, A.P.; Rijsewijk, F.; Roehe, P.M. Vaccination with a gE-negative bovine herpesvirus type 1 vaccine confers insufficient protection to a bovine herpesvirus type 5 challenge. Vaccine 2006, 24, 3313-3320. [CrossRef] [PubMed] 